\title{
„UCZYĆ SIE, ABY ŻYĆ WSPÓLNIE” W KONCEPCJI MIĘDZYNARODOWEJ KOMISJI DO SPRAW EDUKACJI DLA XXI WIEKU
}

Streszczenie: Celem artykułu jest zaprezentowanie założeń dotyczących podstawowych filarów edukacji, określonych przez Międzynarodową Komisję do spraw Edukacji dla XXI wieku, która pracowała pod kierunkiem Jacques’a Delorsa (przewodniczącego Komisji Europejskiej w latach 1985-1995). Pokłosiem obrad Komisji jest Raport dla UNESCO „Edukacja: jest w niej ukryty skarb” („L'Éducation: Un trésor est caché dedans”, UNESCO 1996). W artykule zastosowano kryterium problemowe, odniesione do poszczególnych części raportu i kategorii postaw dotyczących: zrównoważonego rozwoju, procesu wychowania, kształcenia do współżycia z innymi, odkrywania Innego.

Słowa kluczowe: Międzynarodowa Komisja do spraw Edukacji dla XXI wieku, edukacja globalna, rozwój zrównoważony, sztuka nauczania, wychowanie do postaw społecznych, pedagogika ekologiczna

\section{Wprowadzenie}

Z inicjatywy Organizacji Narodów Zjednoczonych do spraw Oświaty, Nauki i Kultury (United Nations Educational, Scientific and Cultural Organization) w 1993 roku powołano Międzynarodową Komisję do spraw Edukacji dla XXI wieku, której przewodniczenie powierzono Jacques’owi Delorsowi. Należy podkreślić, że prace Komisji nawiązywały do raportu Uczyć się, aby być (1972), opracowanego pod przewodnictwem Edgara Faure’a (Faure 1975), szczególnie do postulatu edukacji ustawicznej oraz wszechstronnej, kształtującej postawy twórcze. Efektem tych obrad jest opublikowany w 1996 roku Raport dla UNESCO Międzynarodowej Komisji do spraw Edukacji dla XXI wieku pod przewodnictwem Jacques'a Delorsa „Edukacja: jest w niej ukryty skarb”.

Przedmiotem krytyki naukowej są nie tylko teorie naukowe, dzieła naukowe, ale również zjawiska społeczne. W związku z tym krytyka ta pełni następujące funkcje: 
selekcyjno-weryfikacyjną, doradczo-informacyjną, inspiracyjno-heurystyczną (por. Bezwińska 2006, s. 191-192). Według Janusza Gniteckiego przedmiotem badań pedagogicznych jest edukacja człowieka, który w przestrzeni edukacyjnej przebywa równocześnie w trzech sferach: faktów danych, faktów zadanych, interpretacji i rozumienia faktów danych i zadanych (por. Gnitecki 2008, s. 18). Niniejszy artykuł ma strukturę problemową, podstawę źródłową stanowi wyżej wymieniony raport Międzynarodowej Komisji do spraw Edukacji dla XXI wieku, źródła drukowane Unii Europejskiej (wydane w latach 2010-2015) oraz autorskie dzieła metodologiczne.

\section{Inny - kto to jest?}

„Edukacja jest przede wszystkim wewnętrzną wędrówką, której etapy wyznaczają fazy bezustannego kształtowania osobowości”

(Raport dla UNESCO... 1998, s. 97).

$\mathrm{Na}$ to pytanie można odpowiedzieć, przyjmując różną perspektywę: płci, wieku, wyznania religijnego, pochodzenia społecznego, grupy etnicznej, niepełnosprawności fizycznej lub umysłowej, tożsamości indywidualnej (podmiotowej), tożsamości przedmiotowej (społecznej). Według Stanisława Chrobaka „droga nadziei zaprasza nas, abyśmy też ze swej strony zwrócili się ku Innemu, abyśmy wzięli na siebie ciężar jego braków, cierpień i niedoskonałości” (Chrobak 2008, s. 22), ponieważ „Inny wprowadza w doświadczenie nadziei, ustanawia przestrzeń pytania i powiernictwa" (Chrobak 2009, s. 39).

W myśl Międzynarodowej Komisji do spraw Edukacji dla XXI wieku poznawanie kultur w skali globalnej może służyć lepszemu zrozumieniu społecznej odmienności (por. Raport dla UNESCO... 1998, s. 230) oraz rozwijaniu wszystkich kategorii postaw. Według zaleceń Unii Europejskiej należy chronić dziedzictwo kulturowe, na poziomie krajowym propagować różnorodność kulturową i dialog międzykulturowy, ujmować kulturę w aspekcie swoistego koła zamachowego twórczości, innowacji i jako element stosunków zewnętrznych (por. Zrozumieć politykę Unii Europejskiej... 2014b, s. 2). A także udzielać pomocy w skali globalnej, dostosowanej do potrzeb takich jak np. likwidacja skrajnego ubóstwa i głodu, zapewnienie powszechnej edukacji podstawowej czy dostępu do wody pitnej (por. Zrozumieć politykę Unii Europejskiej... 2014c, s. 2-11).

Warto przypomnieć, że głównym celem Unii Europejskiej jest kreowanie europejskiej przestrzeni sprawiedliwości dla obywateli i sprawiedliwości na rzecz wzrostu (por. Zrozumieć politykę Unii Europejskiej... 2015a, s. 1). Do podstawowych zasad Unii Europejskiej należą m.in.: równouprawnienie kobiet i mężczyzn, niedyskryminowanie i zapobieganie dyskryminacji ze względu na płeć, wiek, pochodzenie rasowe lub etniczne, wyznanie religijne lub przekonania, niepełnosprawność, a także zatrudnianie osób niepełnosprawnych, zapobieganie szeroko 
pojętej przemocy i zwiększanie ochrony oraz wsparcia dla jej ofiar (por. tamże, s. 2). Od 2011 roku Unia Europejska jest również stroną Konwencji Organizacji Narodów Zjednoczonych o prawach osób niepetnosprawnych (która stała się częścią porządku prawnego Unii Europejskiej) (por. tamże, s. 3). Parlament Europejski współtworzy prawo Unii Europejskiej i zapewnia demokratyczną kontrolę innych unijnych instytucji (por. Parlament Europejski 2014... s. 3). Proces poprawy jakości codziennego życia obywateli dotyczy także zwiększenia skuteczności prawa w celu przeciwdziałania dyskryminacji (np. z powodu niepełnosprawności) (por. tamże, s. 12-13). W tym kontekście w Karcie praw podstawowych Unii Europejskiej wymieniono: godność, wolność, równość, solidarność, prawa obywatelskie, sprawiedliwość - jako podstawowe prawa i elementy chronionej wolności (por. tamże, s. 4).

Implikację polityki Unii Europejskiej stanowią badania naukowe oraz innowacje dotyczące problematyki zdrowia, zdrowego stylu życia, ochrony środowiska, zapobiegania wielu chorobom i zagrożeniom, takim jak coraz powszechniej występujące choroba Alzheimera, cukrzyca, odporne na antybiotyki superbakterie (por. Zrozumieć politykę Unii Europejskiej... 2015b, s. 5). W związku z tym dzięki badaniom naukowym opracowuje się innowacyjne terapie, wykorzystujące np. nanocząsteczki w leczeniu choroby Alzheimera, kreuje się „dania z drukarki” dla osób mających trudności z przeżuwaniem lub połykaniem (por. tamże, s. 6), a także wprowadza innowacje mające na celu tworzenie otoczenia przyjaznego dla osób starszych (por. tamże, s. 9). Ważnym zadaniem jest również ochrona kobiet przed przemocą (por. Europa dla kobiet 2010, s. 11), ograniczenie nierówności i wykluczenia społecznego, a także realizowanie badań dotyczących następujących kategorii: pamięć, tożsamość, tolerancja, dziedzictwo kulturowe (por. tamże, s. 8).

Wśród celów oraz przewodnich inicjatyw europejskiej strategii na rzecz wzrostu Europa 2020... wymieniono: zmniejszenie liczby osób zagrożonych ubóstwem lub wykluczeniem społecznym (o $20 \mathrm{mln}$ ), poprawienie rezultatów systemu kształcenia (por. Zrozumieć politykę Unii Europejskiej... 2013, s. 1) przez ograniczenie liczby uczniów przedwcześnie kończących edukację do poziomu poniżej 10\% oraz zagwarantowanie, aby co najmniej 40\% osób w wieku 30-34 lat miało wyższe wykształcenie (por. tamże, s. 3). Za bardzo ważny problem i zarazem kluczowe zadanie uznano lepsze wykorzystanie funduszy unijnych, wspierających politykę społeczną dotyczącą zwalczania dyskryminacji i poszukiwania „inteligentnych” rozwiązań socjalnych (por. tamże, s. 8), sprzyjających integracji społecznej.

Można więc uogólnić, że działania Unii Europejskiej zmierzają do „zjednoczenia w różnorodności” (por. Europa... 2013, s. 14), poszanowania godności ludzkiej, wolności, demokracji, równości, przestrzegania praw człowieka, tolerancji, sprawiedliwości, solidarności, braku dyskryminacji (por. tamże, s. 35), pomocy $\mathrm{w}$ walce $\mathrm{z}$ ubóstwem, analfabetyzmem i zapóźnieniem gospodarczym oraz ochrony środowiska przyrodniczego (por. tamże, s. 41-42). W Traktacie z Lizbony (2007) zapisano, że Unia Europejska nie jest jedynie bytem samym w sobie, lecz powstała i rozwija się na rzecz państw stanowiących oraz ich obywateli, m.in. w zakresie 
edukacji (por. Barcz 2010, s. 9, 43). W związku z tym w krajach Unii Europejskiej są realizowane różnorodnie projekty dotyczące wzajemnego poznania Innych, zrozumienia i akceptacji ich ograniczeń (por. Międzykulturowość... 2008, s. 14), pomocy Innym dzięki m.in. takim inicjatywom jak hipoterapia (por. tamże, 22), pokonywania barier w środowisku zróżnicowanym kulturowo (por. tamże, s. 37-39, 42-46).

\section{Imperatyw lepszego rozumienia siebie i Innego}

„Wykluczenie nie jest wynalazkiem schyłku XX wieku” (Raport dla UNESCO... 1998, s. 229).

Podczas obrad Międzynarodowej Komisji do spraw Edukacji dla XXI wieku podkreślono, że wśród napięć, jakie należy przezwyciężać/redukować w XXI wieku, są: napięcie pomiędzy tym, co globalne, a tym, co jednostkowe; między tradycją a nowoczesnością (bez wyrzekania się własnej tożsamości); między działaniem perspektywicznym a doraźnym; między bardzo szybkim rozwojem wiedzy a zdolnością przyswojenia jej przez ludzi. Należy także redukować konflikt między duchowością i materialnością (por. tamże, s. 17). W procesie edukacji ustawicznej i twórczej Międzynarodowa Komisja do spraw Edukacji dla XXI wieku zaleciła lepsze rozumienie Innego, uczenie się życia wspólnego z Innym (por. tamże, s. 92), poprzez np. wzbogacenie wiedzy o jego historii, tradycji, duchowości (por. tamże, s. 17).

Edukacja musi więc być ustawicznym, trwającym całe życie, procesem kształtowania osoby ludzkiej, jej wiedzy i umiejętności. Powinna umożliwić człowiekowi zdawanie sobie sprawy z własnego jestestwa i swego otoczenia, zwłaszcza lokalnego (por. tamże, s. 102), w którym dana istota żyje i funkcjonuje. Tezę „uczyć się, aby żyć wspólnie" należy rozumieć jako dążenie do pełniejszego zrozumienia Innego, dostrzegania współzależności, realizowania wspólnych projektów, uczenia się rozwiązywania konfliktów z poszanowaniem wartości pluralizmu, wzajemnego zrozumienia i pokoju (por. tamże, s. 98).

Wyjaśniono, że odkrywanie Innego dokonuje się przez poznanie siebie. Wychowanie dziecka w rodzinie, w środowisku lokalnym, w procesie edukacji szkolnej powinno pomóc mu poznać/zrozumieć siebie (odkrywać samego siebie) (por. tamże, s. 94). Tak więc fundamentalnym zadaniem edukacji jest rozwijanie umysłu i duchowości (dyspozycji instrumentalnych i kierunkowych osobowości), wychowywanie do świadomej solidarności, umożliwienie każdemu człowiekowi zrozumienia siebie i innych (por. tamże, s. 44), poznanie swoich korzeni kulturowych oraz znaczenia bogactwa różnorodności kulturowej w skali globalnej. Według Międzynarodowej Komisji do spraw Edukacji dla XXI wieku podstawowym zadaniem edukacji jest umożliwienie ludziom kierowania własnym rozwojem, decydowania o swoim życiu (edukacja na rzecz rozwoju) (por. tamże, s. 79). 


\title{
Imperatyw włączenia rodziny do procesu nauki szkolnej Innego
}

\begin{abstract}
„Zaniechanie wysiłków na rzecz pielęgnowania i zachowania właściwej relacji z bliźnim, wobec którego mamy obowiązek opieki i ochrony, niszczy wewnętrzną relację z samym sobą"
\end{abstract}

(Franciszek 2015, s. 48).

Na proces kształcenia i wychowania dzieci ogromny wpływ ma rodzina jako bardzo ważna instytucja wychowania naturalnego, „pierwsza szkoła dziecka” (por. Raport dla UNESCO... 1998, s. 125). W myśl zaleceń Międzynarodowej Komisji do spraw Edukacji dla XXI wieku należy włączać rodziców do procesu nauki szkolnej (skolaryzacji ich dzieci) (por. tamże, s. 55) i udzielać im pomocy w przezwyciężaniu trudności wychowawczych. W trosce o harmonijny rozwój dzieci trzeba realizować dialog/współdziałanie edukacji szkolnej z edukacją w rodzinie (por. tamże, s. 106). Zwłaszcza w przypadku dzieci o specyficznych potrzebach edukacyjnych, gdy rodzina nie jest w stanie ich zdiagnozować lub zaspokoić, szkoła powinna zaoferować specjalistyczną pomoc w tym zakresie (por. tamże, s. 125) i podjąć walkę z niepowodzeniami szkolnymi (por. tamże, s. 143). Prawidłowo funkcjonująca rodzina jest bowiem najwartościowszym środowiskiem wychowawczym.

\section{Imperatyw wspomagania Innego przez nauczycieli, wychowawców i środowisko lokalne}

\author{
„Uczenie jest sztuką i nic nie jest w stanie zastąpić \\ bogactwa dialogu pedagogicznego" \\ (Raport dla UNESCO... 1998, s. 185).
}

W myśl zaleceń Międzynarodowej Komisji do spraw Edukacji dla XXI wieku nauczyciele powinni znać/rozumieć uwarunkowania kultury ponowoczesnej, służące rozwijaniu postaw poszanowania własnej godności oraz godności Innego. Muszą umieć nawiązać nowy rodzaj relacji z uczniami. Przechodząc od roli „solisty” do roli „akompaniatora”, powinni stawać się dojrzałymi przewodnikami dla swoich uczniów, zarówno w procesie eksploracji, jak i posługiwania się wiedzą (por. tamże, s. 150). Ważne jest też, aby kształcili krytyczne myślenie umożliwiające niezależność sądów (por. tamże, s. 95), stosowali różnorodne zasady kształcenia (przede wszystkim zasadę indywidualizacji) (por. tamże, s. 55) oraz metody kształcenia i wychowania (m.in. metodę dialogu) (por. tamże, s. 25). Jest to konieczne, ponieważ w związku z bardzo szybkim rozwojem naukowym i technologicznym wiedza i umiejętności w dużym tempie się dezaktualizują, i człowiek wymaga ustawicznego dokształcania i doskonalenia umiejętności zawodowych (por. tamże, s. 10o).

Szkoła nie jest jedyną instytucją wychowania bezpośredniego, dlatego współpracuje z innymi instytucjami wychowania naturalnego, bezpośredniego i pośredniego $-\mathrm{z}$ szeroko pojętym środowiskiem wychowującym. Musi być otwarta na 
wszystkie obszary kultury właściwe dla danego kraju, zwłaszcza na muzea, teatry, biblioteki (por. tamże, s. 110). Powinna poszukiwać możliwych synergii między wiedzą teoretyczną i praktyczną, między indywiduum danej osoby i społeczeństwem (por. tamże, s. 112), co ważne - zgodnie z ideą społeczeństwa wychowującego, w którym dana jednostka uczy się i rozwija swoje talenty przez całe życie (por. tamże, s. 113).

Według Raportu dla UNESCO Międzynarodowej Komisji do spraw Edukacji dla XXI wieku pod przewodnictwem Jacques'a Delorsa „Edukacja: jest w niej ukryty skarb" edukacja podstawowa jest przygotowaniem do życia i bardzo dobrym okresem, aby „uczyć się uczyć” (pracować nad sobą) (por. tamże, s. 123). Jest edukacją wstępną (formalną lub nieformalną) od około 3. roku życia do co najmniej 12. roku życia. Ma wyzwolić potencjał uczenia się, również w przypadku dzieci o specyficznych potrzebach edukacyjnych (np. sierot, dzieci ulicy, ofiar wojen) (por. tamże, s. 125). Stanowi swoisty „paszport do życia”, który umożliwi jego posiadaczom kontynuowanie nauki (por. tamże, s. 120).

Można dodać, że także według konstatacji Komisji Europejskiej inwestycja $\mathrm{w}$ proces kształcenia ma zasadnicze znaczenie w procesie zwiększania szans na zatrudnienie (por. Zrozumieć politykę Unii Europejskiej... 2014a, s. 1). Stwierdzono, że około 20\% mieszkańców Unii Europejskiej nie posiada podstawowych umiejętności z zakresu czytania, matematyki i nauk przyrodniczych. Z tego powodu osobom o specjalnych potrzebach edukacyjnych oraz przedwcześnie kończącym naukę mogą pomagać np. emeryci, którzy pełnią funkcję mentorów (por. tamże, s. 2), realizują swoje pasje, pomagając innym (por. Może wolontariat? 2012, s. 7-9).

W przypadku osób niepełnosprawnych intelektualnie uczenie się przez całe życie nie ogranicza się do procesu nabywania nowych umiejętności, lecz polega na umożliwieniu im integracji społecznej, występowania we własnym imieniu i przejmowania większej kontroli nad swoim codziennym życiem (por. tamże, s. 5). Cenne jest również zdobywanie doświadczeń zagranicznych i nowych perspektyw zawodowych poprzez poszerzanie dotychczasowych sieci interpersonalnych w zakresie kompetencji dotyczących języka migowego, dzięki np. takim inicjatywom jak staż zagraniczny w Federacji Głuchoniemych na Cyprze (por. tamże, s. 10-11).

W myśl ustaleń Komisji Europejskiej cudzoziemcy, statystycznie rzecz ujmując, stosunkowo szybko kończą naukę szkolną. Może to wynikać z faktu, że doświadczają trudności w dostępie do edukacji z powodu barier: językowych, kulturowych, a nawet niższego statusu społeczno-ekonomicznego (por. Wnioski z raportu Eurydice... 2015, s. 2). Poradnictwo edukacyjne i zawodowe może być jednym z kluczowych środków zapobiegających zbyt wczesnemu kończeniu nauki (por. tamże, s. 3) tej kategorii Innych. Należy do nich także ewaluacja pracy instytucji dydaktyczno-wychowawczych w celu podjęcia przez szkołę działań naprawczych w tym zakresie (por. Zapewnienie jakości... 2015, s. 1-2), podnoszenia jakości edukacji szkolnej (z udziałem kadry nauczającej, rodziców, uczniów oraz przedstawicieli środowisk lokalnych związanych ze szkołą) (por. tamże, s. 4), co może również 
pozytywnie służyć włączeniu osób wykluczonych społecznie w obszar aktywności zawodowej (por. Komunikat Komisji... 2010, s. 35).

\section{Zakończenie}

„Obok dobra indywidualnego istnieje dobro związane ze współżyciem społecznym osób: dobro wspólne"

(Benedykt XVI 2009, s. 9).

Według tez/założeń ogólnych kultury ponowoczesnej (postindustrialnej, społeczeństwa wiedzy, w warunkach globalnej eklektyki kulturowej różnorodności, pluralizmu) tożsamość nie jest dana, lecz zadana, każdy człowiek/osoba staje się Innym. Formułując konkluzję, można nawiązać do działalności naukowej George'a Herberta Meada (interakcjonizm symboliczny) i podkreślić, że w procesie socjalizacji jednostka (jako indywiduum społeczne) stopniowo dojrzewa psychicznie do stadium „uogólnionego Innego”, pokonuje naturalne kryzysy rozwojowe (o których pisał również Erik Erikson). Ma niepowtarzalną osobowość, właściwą sobie psychosferę i szeroko pojęte środowisko wychowujące. W procesie kulturalizacji/enkulturacji nabywa kompetencje kulturowe, dzięki procesowi socjalizacji (pierwotnej i wtórnej) zdobywa kompetencje społeczne, co przekłada się na jakość wielu postaw - w ich aspekcie poznawczym, emocjonalnym, działaniowym (np. ideowych, społecznych, kulturowych, interpersonalnych, intrapersonalnych, egzystencjalnych, intelektualnych). Można sądzić, że również z tego powodu w Raporcie dla UNESCO Międzynarodowej Komisji do spraw Edukacji dla XXI wieku pod przewodnictwem Jacques'a Delorsa „Edukacja: jest w niej ukryty skarb” tak dużo uwagi poświęcono jednemu z czterech filarów edukacji: „uczeniu się, aby żyć wspólnie, uczeniu się współżycia $\mathrm{z}$ innymi”, w powiązaniu z pozostałymi trzema filarami edukacji: „uczeniem się, aby wiedzieć”, „uczeniem się, aby działać”, „uczeniem się, aby być”.

Rekapitulując, zacytuję następującą refleksję papieża Franciszka: „Bądźmy opiekunami stworzenia [...], opiekunami bliźniego, środowiska. [...] Troska, ochrona wymagają, by były one przeżywane $\mathrm{z}$ wrażliwością. [...] Jest to ochrona ludzi, troska z miłością o wszystkich, każdą osobę, zwłaszcza o dzieci i osoby starsze, o tych, którzy są istotami najbardziej kruchymi i często znajdują się na obrzeżach naszych serc" (Franciszek 2015, s. 18-19, 22).

\section{Bibliografia}

Barcz J. (2010). Poznaj Traktat z Lizbony. Wrocław: Ministerstwo Spraw Zagranicznych. 
Benedykt XVI (2009). Encyklika Caritas in veritate. O integralnym rozwoju ludzkim w miłości i prawdzie. Do biskupów i diakonów, do osób konsekrowanych $i$ wszystkich wiernych świeckich. Kraków: Wydawnictwo M.

Bezwińska T. (2006). Badacz jako krytyk. W: Kubinowski D., Nowak M. (red.). Metodologia pedagogiki zorientowanej humanistycznie (Seminaria metodologii pedagogiki polskiej - Towarzystwo Pedagogiczne). Kraków: Oficyna Wydawnicza Impuls.

Chrobak S. (2008). W poszukiwaniu Innego - nadzieja chrześcijańska nadzieja dla człowieka. W: Dycht M., Marszałek L. (red.). Wobec „odmienności...?”. Pedagogiczne konotacje. Warszawa: Wydawnictwo Salezjańskie.

Chrobak S. (2009). Żyć razem z innym i obcym - przestrzenie i drogi nadziei. W: Chrzanowska I., Jachimczak B., Podgórska-Jachnik D. (red.). Miejsce Innego we współczesnych naukach o wychowaniu. Trudy dorastania, trudy dorosłości. Łódź: Wyższa Szkoła Pedagogiczna.

Europa dla kobiet (2010). Luksemburg: Urząd Publikacji Unii Europejskiej.

Europa. Informator dla młodzieży (2013). Luksemburg: Urząd Publikacji Unii Europejskiej.

Faure E., Herrera F., Kaddoura A.R., Lopes H., Pietrowski A.W., Rahnema M., Ward F.Ch. (1975). Uczyć się, aby być, tłum. Zakrzewska Z., przedmowa do wyd. pol. Kupisiewicz C. Warszawa: Państwowe Wydawnictwo Naukowe.

Franciszek (2015). Encyklika Laudato Si'. W trosce o wspólny dom. Kraków: Wydawnictwo M.

Franciszek (2013). Myśli, wybór i red. Kuzioła W. Częstochowa: Edycja Świętego Pawła.

Gnitecki J. (2008). Eksplikacja pojęcia „przedmiot badań pedagogiki”. W: Rubacha K. (red.). Konceptualizacje przedmiotu badań pedagogiki (Seminaria metodologii pedagogiki polskiej - Towarzystwo Pedagogiczne). Kraków: Oficyna Wydawnicza Impuls.

Komunikat Komisji „Europa 2020 - Strategia na rzecz inteligentnego i zrównoważonego rozwoju sprzyjającego włączeniu społecznemu" (2010). Bruksela: Komisja Europejska.

Międzykulturowość w projektach programu „Młodzież w działaniu”. Zeszyt tematyczny: dialog międzykulturowy (2008). Warszawa: Fundacja Rozwoju Systemu Edukacji.

Może wolontariat? (2012) W: Aktywny senior. Dodatek do „Newsweek”, we współpracy z Przedstawicielstwem Komisji Europejskiej w Polsce.

Parlament Europejski. Jak działa? (2014). Wrocław: Biuro Informacyjne Parlamentu Europejskiego w Polsce.

Raport dla UNESCO Międzynarodowej Komisji do spraw Edukacji dla XXI wieku pod przewodnictwem Jacques'a Delorsa „Edukacja: jest w niej ukryty skarb” (1998), tłum. Rabczuk W. Warszawa: Stowarzyszenie Oświatowców Polskich Wydawnictwa UNESCO. 
Wnioski z raportu Eurydice. Ograniczenie zjawiska wczesnego kończenia nauki: polityka, strategia, działania (2015). Warszawa: Polskie Biuro Eurydice, Fundacja Rozwoju Systemu Edukacji.

Zapewnienie jakości w edukacji: ewaluacja szkół w Europie - polityka i stosowane rozwiązania (wnioski z raportu Eurydice) (2015). Warszawa: Fundacja Rozwoju Systemu Edukacji.

Zrozumieć politykę Unii Europejskiej: sprawiedliwość, prawa podstawowe i równość (2015a). Luksemburg: Dyrekcja Generalna ds. Komunikacji Społecznej (wydział Komisji Europejskiej), Urząd Publikacji Unii Europejskiej.

Zrozumieć politykę Unii Europejskiej. Badania naukowe i innowacje (2015b). Luksemburg: Dyrekcja Generalna ds. Komunikacji Społecznej (wydział Komisji Europejskiej), Urząd Publikacji Unii Europejskiej.

Zrozumieć politykę Unii Europejskiej. „Europa 2020 - europejska strategia na rzecz wzrostu" (2013). Luksemburg: Dyrekcja Generalna ds. Komunikacji Społecznej (wydział Komisji Europejskiej), Urząd Publikacji Unii Europejskiej.

Zrozumieć politykę Unii Europejskiej. Kształcenie, szkolenie, młodzież i sport (2014a). Luksemburg: Dyrekcja Generalna ds. Komunikacji Społecznej (wydział Komisji Europejskiej), Urząd Publikacji Unii Europejskiej.

Zrozumieć politykę Unii Europejskiej. Kultura i polityka audiowizualna (2014b). Luksemburg: Dyrekcja Generalna ds. Komunikacji Społecznej (wydział Komisji Europejskiej), Urząd Publikacji Unii Europejskiej.

Zrozumieć politykę Unii Europejskiej. Wspótpraca międzynarodowa i rozwój (2014c). Luksemburg: Dyrekcja Generalna ds. Komunikacji Społecznej (wydział Komisji Europejskiej), Urząd Publikacji Unii Europejskiej.

\title{
"LEARNING WITH THE VIEW TO LIVE TOGETHER" IN THE CONCEPT OF THE INTERNATIONAL COMMISSION ON EDUCATION FOR THE TWENTY-FIRST CENTURY
}

\begin{abstract}
The aim of the article is to present assumptions concerning the basic pillars of education, defined by the International Commission on Education for the Twenty-first Century, which operated under the supervision of Jacques Delors (President of the European Commission in the years 1985-1995) Learning: The Treasure Within (original title: L'Éducation: Un trésor est caché dedans, UNESCO 1996). The criterion applied in the article is the problem, referred to particular categories of attitudes concerning sustainable development, the process of education, developing the skill of coexistence with others, discovering the other one.
\end{abstract}

Key words: International Commission on Education for the Twenty-first Century, global education, sustainable development, the art of teaching, developing social attitudes, ecological pedagogy 
Edyta Wolter - doktor habilitowana, pedagog, historyk edukacji, profesor nadzwyczajna w Katedrze Historii Wychowania i Dziejów Oświaty na Wydziale Nauk Pedagogicznych Uniwersytetu Kardynała Stefana Wyszyńskiego w Warszawie. Zainteresowania naukowe, główne kierunki badań: kulturowe uwarunkowania edukacji ekologicznej w Polsce, pedagogiczne aspekty równoważenia rozwoju w środowisku społeczno-przyrodniczym, pedagogiczne implikacje ekologii człowieka, pedagogika ekologiczna, edukacja ekologiczna w Drugiej Rzeczypospolitej, edukacja ekologiczna dzieci. Autorka 155 publikacji naukowych,w tym czterech książek autorskich. Adres e-mail: e.wolter@uksw.edu.pl. 